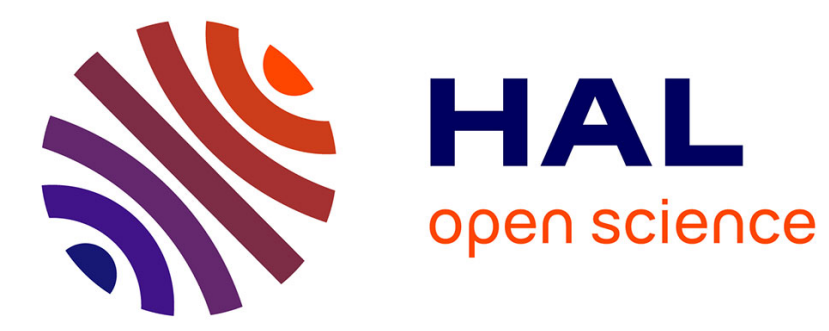

\title{
Special issue Proceedings of 31st International Symposium on Chirality, Bordeaux, 2019
}

Reiko Oda, Jeanne Crassous, Nina Berova, Gennaro Pescitelli, Oliver Trapp

\section{To cite this version:}

Reiko Oda, Jeanne Crassous, Nina Berova, Gennaro Pescitelli, Oliver Trapp. Special issue Proceedings of 31st International Symposium on Chirality, Bordeaux, 2019. Chirality, 2020, 32 (8), pp.1035-1036. 10.1002/chir.23238 . hal-02862239

HAL Id: hal-02862239

https://hal-univ-rennes1.archives-ouvertes.fr/hal-02862239

Submitted on 21 Apr 2021

HAL is a multi-disciplinary open access archive for the deposit and dissemination of scientific research documents, whether they are published or not. The documents may come from teaching and research institutions in France or abroad, or from public or private research centers.
L'archive ouverte pluridisciplinaire HAL, est destinée au dépôt et à la diffusion de documents scientifiques de niveau recherche, publiés ou non, émanant des établissements d'enseignement et de recherche français ou étrangers, des laboratoires publics ou privés. 


\title{
Special issue: Proceedings of 31st International Symposium on Chirality, Bordeaux, 2019
}

\author{
R. Oda, J. Crassous, N. Berova, G. Pescitelli, O. Trapp
}

The 31st International Symposium on Chirality - Chirality 2019, held in Bordeaux, France, from 14 to 17 July 2019, was a great success with the participation of 340 scientists from 28 countries. The symposium started with two short courses given by four renown professors on "Chiroptical Spectroscopy Methods for Structural Analysis of Chiral Molecules" (G. Longhi and P. Polavarapu) and "Materials" (A. Palmans and G. Markovich). During the following 3 days, we had wonderful invited Plenary and Keynote lectures for which $40 \%$ were women lecturers, as well as 58 oral lectures and two poster sessions (162 posters). Very lively discussions and exchanges between the researchers were also observed. We were very happy to have Prof. Larry Nafie who received the Chirality Medal for his seminal contributions to the development and application of vibrational optical activity (VOA). This year, we also had special presentations on "Enantioseparations" honoring some of the founders of the Chirality conferences. We are extremely grateful to the generous academic and industrial sponsors and to the local organizing commit- tee without whom this event would not have been possible.

During the symposium, with the great participations from BioTools, Organic Biomolecular Chemistry Journal, INITIO European project, and Association Française de Cristallographie, six poster prizes have been awarded to the following PhD students and post- doctorants: Hinako Okutsu (Nagoya University, Japan), Kakali Santra (Weismann Institute, Israel), Benjamin Martial (Laval University, Canada), Caoimhe Bond (Queen's University Belfast, UK), Ghislaine Vantomme (Eindhoven University, The Netherlands), and Flavia Pop (University of Angers, France).

We do hope that all the participants appreciated the friendly atmosphere, the social program (French cuisine, Bordeaux wine Chateau, Beautiful city center, and so forth) and that we could soon welcome all of them back in Bordeaux!

We are very proud of this special virtual issue with eight very high-quality articles by experts in chirality related domains embracing (i) a minireview from our Chirality Medal winner (L. Nafie), (ii) a tribute to Bill Pirkle (C. Welch), and articles on (iii) chiral encaged Verkade's Superbases (A. Martinez), (iv) chiral supra- molecular assemblies in polymer matrices (H. Jintoku),

(v) computational aspects of ROA (P. Bour),

(vi) hierarchical expression of chirality in aggregates (R. Oda), (vii) autocatalytic chiral amplification effects (M. Amedjkouh), and (viii) solid-state synthesis of chiral cyclodipeptides (A. Zehnacker). 